\title{
The GIS Analysis Use to Assess the Ecological and Economic Risks in Infrastructure Projects
}

\author{
Nadezhda V. Pomazkova \\ Institute of Natural Resources, Ecology and Cryology SB \\ RAS \\ Chita, Russia \\ naste2@yandex.ru
}

\author{
Larisa M. Faleychik \\ Institute of Natural Resources, Ecology and Cryology SB \\ RAS \\ Chita, Russia \\ 1faleychik@bk.ru
}

Andrey A. Faleychik

Transbaikal State University

Chita, Russia

faa55@bk.ru

\begin{abstract}
At present, Transbaikalia is territorially located in the interests zone of the largest foreign policy initiative of China- the project "Silk Road Economic Belt". The project provides a comprehensive deepening of trade-economic ties between Asia-Pacific countries. The creation of the infrastructure linking member states (China, Russia, Mongolia) is one of the priority directions of this cooperation. First of all, the possibility of constructing a high-speed railway (HSR) is considered. Analysis of the literature shows that HSRs exert an overall positive effect on the development of regional economies, especially on such brunches as tourism, information technology and regional cooperation. At the same time, like any economic entity, this initiative carries risks for the natural ecosystems of the region. The article considers some individual environmental aspects of this project in the Trans-Baikal Territory. The purpose of the research is to identify and estimate the territory valuable natural areas loss risk in the case of HSR project implementation. The results of spatial analysis in GIS show that the project is likely to endanger 43 out of 122 natural geosystems located in the Trans-Baikal Territory. According to the proposed route version, it won't cross any border of any nature reserve. The measures to mitigate and compensate for the negative impact of the new transport facility on the region geosystem are proposed.
\end{abstract}

Keyword - high-speed railway; risk assessment; nature protected areas; GIS technology

\section{INTRODUCTION}

t present, Trans-Baikal Territory (TBT) is territorially located in the zone of interests of the largest foreign policy initiative of China - Silk Road Economic Belt (SREB), a part of the system project One Belt, One Road (OBOR). SREB concept provides a comprehensive deepening of trade-economic, transport and logistics links between the countries of Asia-Pacific region, a priority avenue of cooperation is the creation of the infrastructure that will link member states (China, Russia, Mongolia). In the first place the possibility of building a highspeed traffic artery is considered.
The study of high-speed networks impact on the economies of adjacent territories shows the total positive effect for regional development [17], especially in such areas as tourism, information technology development and regional cooperation [18]. At the same time, like any other economic entity, the initiative carries risks for the natural ecosystems of the region. Not only during the construction period, but also as a new member of regional economy, the road will propel the region development being the onset of the possible consequences in the future since it will cause changes in land use and settlement and will stimulate the further development of the road network itself, and so on.

However, the population of the eastern regions of Russia bordering China worries about Russian-Chinese cooperation projects. Long-term experience of cross-border cooperation shows that the socio-economic prospects often entail challenges, including environmental ones [5]. The situations of ecologically unequal exchange when short-term benefits go to investors whereas the public faces irreversible changes in ecosystems up to environmental disasters occur rather often [16].

The formation of projects and programs of Silk Road Economic Belt should be based on the principles of "green" economy and not allow for changes in the existing environmental and economic situation for the worse. A New Silk Road should become a road to "green" economy for TBT [7].

The interest to the issues of roads impact on the surrounding area and landscapes becomes weaker, as can be seen from regular publications on this subject $[1,3]$. However, most publications are focused on the issues of sustainable transport development, life quality improvement, land use patterns changes and so forth [8]. Much less studies are devoted to the influence of high-speed railways on natural ecosystems. They often discuss "environmental" benefits of HSRs only compared to conventional railways, road and air transport because they are more energy efficient, produce less GHG (greenhouse gases) and dust, have a lower level of noise 
impact or the infrastructure protecting against it, occupy a smaller land in comparison with a highway and so on [9].

Direct and indirect impact, the cumulative effect of all the factors on the landscape as a system are less studied, however it is noted that roads and road networks have a synergistic effect on ecosystems [4]. Since most of the roads cross a few types of landscapes and ecosystems, the numerous attempts of comprehensive ecological and economic risk and vulnerability assessment of ecosystems using different indices were made. The intensity and area of road impact on the surrounding area change over time and may have different coverage, depending on the sensitivity and vulnerability of species and ecosystems. Currently, the tools to assess all the complex of roads impact are not sufficiently developed [14].

However, it was found that road impact goes far beyond just the railroad bed or a land plot designated for its allocation. Riitters and Wickham (2003) [15], found that the maximum cumulative exposure of a road is confined in a $100 \mathrm{~m}$ zone along it, but in most cases (83\%) the impact extends for $1 \mathrm{~km}$, and on the whole it is registered at a distance of $5 \mathrm{~km}$. This zone can be asymmetrical, with intricate borders reflecting the geomorphological and other features of the area.

The objectives of this study do not include the assessment of the impact made by the entire range of factors and comprehensive coverage of the problems that arise when implementing this initiative. The purpose is to identify and evaluate the territory natural areas loss risks when implementing this project and the need for their inclusion in the existing network of NPAs (nature protected areas).

\section{MATERIAL AND METHODS}

The tasks of the identification of the natural complexes, which may be affected by exposure to various aspects of the construction and operation of HSR, were solved in the GIS application ArcGIS Desktop using both systemic and specially created authoring tools for geoprocessing [2].

The data of the interferometric recording of the globe, Shuttle Radar Topography Mission (SRTM), were used as a general geographic base. The vector thematic layers, representing the topographic base of the territory, infrastructure objects and thematic layers of the map "The landscapes of the south of the Eastern Siberia" of 1: 1500000 scale [11], existing NPA network circuits and designed protected areas according to Integrated NPA Development Program in Zabaykalskiy region were used in spatial analysis.

In addition, the results of the authors' earlier studies were used for the landscapes evaluation and classification $[12,13]$.

\section{RESULTS AND DISCUSSION}

In accordance with physiographic zoning scheme HSR line crosses the following physiographic regions and provinces: Central Asian desert-steppe region and two provinces of South. Siberian mountainous area - Ingodino-Onon basin midmountain area and Khilok-Udinsk steppized midmountain area. Mountainous basin relief determines the location of the planned object along the bottom of the slopes and in river valleys. Thus, steep and meadow coenoses along rivers will be increasingly affected, as well as treeless or steep areas at the foot of slopes. Taiga landscapes of the middle and upper parts of the ridges in the places of their intersection with transport corridor will be affected to a lesser extent.

Spatial analysis performed in ArcGIS allowed revealing landscapes and protected areas falling in the transport corridor - a buffer zone, constructed along the planned HSR ( $5 \mathrm{~km}$ from the both sides of the road). In accordance with the landscape map [11] 43 of 122 geosystems forming the landscape structure of TBT fall in this corridor (Fig. 1). The abundance of each geosystems identified in the territory of the region as well as its representation in the existing network of NPAs were assessed.

Among steppe geosystems the anticipated impact area is characterized by very rare for TBT slope stony low forb Artemisia lithophile (198), folds bottoms, low-bushgrass spotted in combination with halophytic-meadow (217) geosystems. If the latters are sufficiently represented in other areas of TBT, the extinction danger of the firsts is amplified by the fact that the impact zone comprises $72 \%$ of their total area in TBT. Piedmont tallgrass feather-agropyron landscape (202) are also endangered, $95.7 \%$ Transbaikalian areas of which fall in the impact zone of the planned HSR.

Among boreal landscapes the most typical geosystems are slope larch, larch-birch and larch-pine forests with mixed undergrowth. In TBT there are very limited number of the analogues of Southern Siberia natural geosystems (dark coniferous and pine subtaiga geosystems) and representatives of the Amur-Sakhalin subtaiga area. The suppositional impact corridor will cover the territory of the valleys, alluvial cones, lower parts and foot of the slopes, so here we deal with a number of geosystems, stenotopic in TBT.

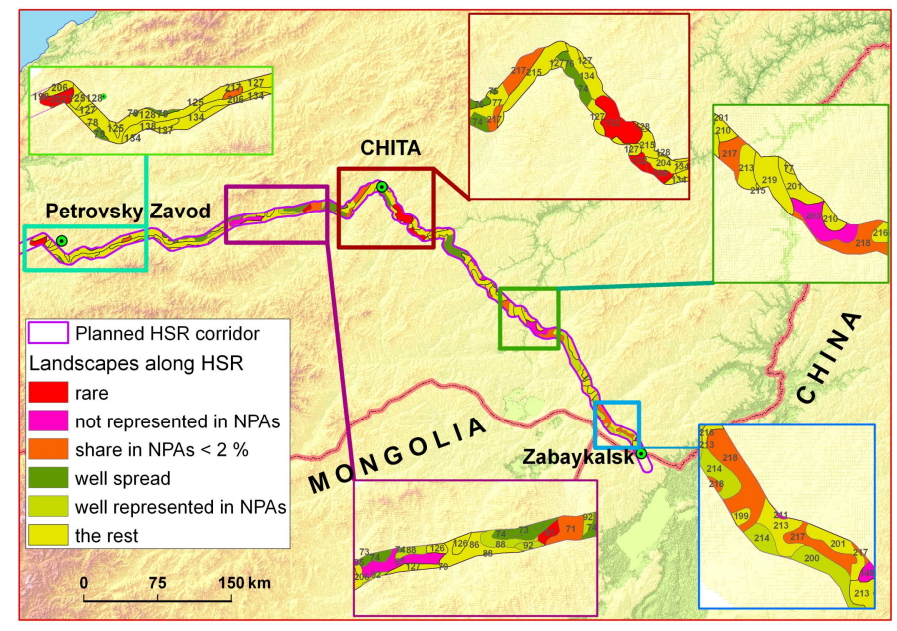

Fig. 1. Natural complexes of TBT in the corridor of the planned HSR

In Fig. 1 the geosystem numbers are given in accordance with the map "Landscapes of the south of Eastern Siberia" [11] and are indicated below in the text in brackets.

Slope larch pine grass-cowberry (81) landscapes are the rarest of TBT taiga geosystems. They cover only a very small proportion of the territory of TBT - less than $0.01 \%, 99 \%$ of which fall in the impact corridor of the planned HSR. 
Transbaikalian rare landscapes include Amur-Sakhalin landscapes formations. The impact zone includes an area of piedmont subtaiga birch landscapes of Dahurian type with meadow steppes and bushes (148), but the share of this area in the total area of the geosystem of this type in TBT is $1.1 \%$. And it is almost completely affected by human activities so far.

All completely or partially pine landscapes are of special natural and economic value $(125,126,127,128,134,138)$, but they are significantly violated by logging and fires [10]. All pine landscapes have limited distribution, in Transbaikalian landscape structure their share ranges from $0.16 \%$ to $1.55 \%$ [12]. The new project endangered plain and valley subtaiga pine landscapes with Dahurian rhododendron undergrowth (132) which represent pine forests, limitedly located on the sides of the rivers valleys confined to sandy soils. The planned transport corridor comprises about $25 \%$ of this landscape area in TBT. Currently, this landscape is already significantly violated along the railway line. According to estimates, from 60 to $80 \%$ of its area were subjected to cutting downs, fires or are allocated for building construction. For this reason its territory in the impact corridor cannot be included in NPAs of the region. It is necessary to find other areas that remained the most pristine.

Rare landscapes (5 types) and landscapes that are not included in the existing network of NPAs (6 types) are at the greatest risk as well as those of geosystems, the total share of which in NPAs network is very small (less than $2 \%$ ) (3 types).

As for the risks and threats of the projected HSR impact on the existing NPAs system of the region, in accordance with the proposed track variant it does not cross the boundaries of any nature protected area. However, in the vicinity of HSR there are several NPAs the environment formation and, consequently, security function of which is under the threat. These are two NPAs of federal status (northern cluster State Nature Biosphere Reserve "Daursky", "Adon-Chelon" area and the federal reserve "Dzeren Valley"), 1 reserve of regional status, 1 natural park, 14 natural monuments, 3 recreational facilities (spas and health and recreation areas).

\section{CONCLUSIONS AND RECOMMENDATIONS}

To reduce the risk of loss and mitigate the impact on natural ecosystems the following measures are recommended at the design stage:

- - HSR line should be designed taking into account a territory landscape structure in order to possibly eliminate the risk of losing rare geosystems and minimize the possible impact on natural systems;

- - landscapes, the risk of loss of which cannot be excluded should be included into the existing network of regional NPAs as compensation measures;

- -200-meter overpasses to reduce landscape fragmentation effect and preserve migration corridors for animals should be envisaged;

- - the route should pass through the previously anthropogenically affected areas only;
- - the territories of rare for TBT landscapes should be excluded from projection zone (area of intense HSR exposure) especially during the construction: slope stony short-grass artemisia lithophile (198), slope pinelarch cowberry forb (81) landscapes;

- - subtaiga pine geosystems with the undergrowth of Dahurian rhododendron (132) and piedmont larch taiga meadow with gramineous cover (85) in the areas, where they are preserved in the most pristine state should be included in the integrated of Transbaikalian NPAs development scheme.

The authors believe that taking into account of the natural and territorial characteristics of the Trans-Baikal Territory when designing transport infrastructure in its territory in the framework of China Silk Road Economic Belt initiative will not contradict the stated environmental objectives of the strategy - environmental safety. The implementation of the proposed measures to eliminate and reduce risks for natural complexes will contribute to the sustainable economic development of the region areas surrounding the transport corridor. And it will allow us to hope that the New Silk Road will be a way to "green" economy for the Trans-Baikal Territory [6].

\section{ACKNOWLEDGMENT}

This article is written in the framework of the Project XI.174.1.8. upon the Program of Fundamental Scientific Researches of Siberian Branch of RAS

\section{REFERENCES}

[1] Steven P. Brady and Jonathan L. Richardson, "Road ecology: shifting gears toward evolutionary perspectives", Frontiers in Ecology and the Environment, vol. 15, no. 2, pp. 91-98, 2017. http://dx.doi.org/10.1002/fee.1458

[2] L. M. Faleychik,. "The GIS models in the assessment of damage for natural systems due to the economic activities", Transbaikal State University Journal, no. 8, pp. 38-51, 2014.

[3] R. T. T. Forman and L. E. Alexander, "Roads and their major ecological effects", Annual Review of Ecology and Systematics, no. 29, pp. 207232, 1998. http://dx.doi.org/10.1146/annurev.ecolsys.29.1.207

[4] R. T. T. Forman, D. Sperling, J. A. Bissonette, A. P. Clevenger, C. D. Cutshall, V. H. Dale, L. Fahrig, R. France, C. R. Goldman, K. Heanue, J. A. Jones, F. J. Swanson, T. Turrentine and T. C. Winter, "Road ecology: science and solutions", Island Press, Washington, 2003.

[5] I. P. Glazyrina, A. A. Faleichik and L. M. Faleichik, "Cross-border cooperation in the light of investment processes: more minuses than pluses so far", Problems of Economic Transition, vol. 55, no. 6, pp. 43$62,2012$.

[6] I. P. Glazyrina and I. A. Zabelina, "Prospects for "green" growth in eastern Russia and the New Silk Road", ECO, no. 7, pp. 5-20, 2016.

[7] I. P. Glazyrina and I. A. Zabelina, "Silk road economic belt and green growth in the East of Russia", Journal of Resources and Ecology, vol. 7, no. 5, pp. 342-351, 2016. http://dx.doi.org/10.5814/j.issn.1674764x.2016.05.004.

[8] C. Hunter, J. Farrington and W. Walton, "Transport and the environment”. In: Hoyle, B., Knowles, R. (Eds.), Modern Transport, 1998.

[9] M. Janic, “A multidimensional examination of performances of HSR (High-Speed Rail) systems", J. Mod. Transport, vol. 24, no. 1, pp. 1-21, 2016. http://dx.doi.org/10.1007/s40534-015-0094-y. 
[10] V. P. Makarov, O. F. Malykh, I. V. Gorbunov, L. N. Pak, T. V. Zhelibo and E. A. Banschikova, "State and the natural regeneration of pine forests after fires in the suburban area of Chita", Advances in current natural sciences, no. 10, pp. 79-83, 2016.

[11] V. S. Mikheev and V. A. Ryashin, "Landscapes of the south of the Eastern Siberia. Map of 1:1500000 scale", V. B. Sochava (Ed.), Moscow, SDGS, 1977.

[12] N. V. Pomazkova and L. M. Faleychik, "Evaluation landscape diversity of the Transbaikal region", Transbaikal State University Journal, no. 9, pp. 23-36, 2013.

[13] N. V. Pomazkova, O. K. Kirilyuk and L. M. Faleychik, "Evaluation of potential security and current state of the landscapes of the Southeast of Transbaikalia", Vestnik of the Siberian State University of Geosystems and Technologies (SSUGT), no. 4, pp. 208-222, 2016.

[14] L. Ries, R. J. Fletcher, J. Battin and T. D. Sisk, "Ecological responses to habitat edges: mechanisms, models and variability explained", Annual
Review of Ecology, Evolution, and Systematics, no. 35, pp. 491-522, 2004. http://dx.doi.org/10.1146/annurev.ecolsys.35.112202.130148

[15] K. H. Riitters and J. D. Wickham, "How far to the nearest road?", Frontiers in Ecology and the Environment, vol. 1, no. 3, pp. 125-129, 2003. http://dx.doi.org/10.2307/3867984

[16] I. A. Zabelina and E. A. Klevakina, "Environmental and economic aspects of natural resource use and problems of cross-border cooperation in regions of Siberia", Problems of Economic Transition, vol. 55, no. 7, pp. 39-48, 2012.

[17] Ming Zhang, Qing Wu, Dianting Wu, Lin Zhao, and Xi Liu, "Analysis of the influence on regional economic development of high-speed railway", Journal of Chemical and Pharmaceutical Research, vol. 6, no. 8, pp. 243-254, 2014.

[18] Shaoying Zhong, Yebo Guo, "The Impact of accessibility of railway network with the high-speed railway construction in China", Areal Research and Development, no. 2, pp. 46-51, 2013. 